\title{
THE ACTANTIAL MODEL AS A PROJECT ACTIVITY IN LITERATURE TEACHING
}

\author{
Valentina Nikolovska PhD \\ High school Taki Daskalo, Bitola, Republic of North Macedonia \\ nikolovskatina@gmail.com
}

\begin{abstract}
The purpose of this paper is to show that the actantal model as a strategy for vertical reading of drama text, is both methodologically and methodicaly appropriate in organizing project activities, due to the fact that it provides a high level of student independence in the research work. Once they have mastered the basic theoretical knowledge, which requires only a few efficiently organized lessons, they will already be able to apply it themselves as a methodical (and methodological) tool for vertical reading of dramatic (but also other, narrative) text.

The role of the teacher in the project activity in teaching is to set goals and objectives on a particular topic, to encourage the students to creative research, to suggest up-to-date and current content and methods, to encourage the students' socialization and together with them to evaluate their results critically.

The role of the students in the project activity in teaching is that they take the initiative to work, that is in line with their own interests and abilities, they actively plan the work course, they look for a solution to the posed problem, and participate in self-assessment and evaluation of the results of the project.
\end{abstract}

Keywords: project activity, activity evaluation, actant, actantial triangles, models in opposition.

\section{Introduction}

The word 'project' possesses Latin origin "projicere" with the meaning "draft, sketch, elaborated plan, work proposal, procedure, social, literary or artistic work, legal text, etc."

The founder of the idea for project teaching is an American pedagogist (John Dewey, 1859-1952) who advocated for child-centered education. At the beginning of the 20th century he warned of four basic natural interests in children: interest in conversation and contact with people, interest in research, interest in creation and construction, as well as interest in artistic research.

Project teaching is maximally interactive, enabling a high degree of teamwork between the students - participants in the project and between the teacher and the students in a way that it stimulates the development of students' research, organizational, communication and critical abilities and fosters the teamwork and partner relationships of all the students.

In the literature there are various definitions of project activity in teaching, as an activity that is often recommended and present in contemporary teaching. This form of knowledge encourages students' curiosity and learning with understanding, as opposed to the traditional form of teaching that is based on the accumulation of data and facts.

In the process of teaching Macedonian language and literature, there can be applied different forms of project activities, depending on the content and the degree of complexity.

a) According to the content

This would include all the plays that are provided in the syllabus (drama texts that are elaborated during the lessons and the books, which are planned to be elaborated once a month). 
b) By the degree of its complexity

The project activities can be simpler and more complex.

They are simpler when students are given the task alone, individually, to construct the actantial models or actantial triangles for particular dramas or drama situations and to self-justify or read them with an elemental analysis.

They are more complex when working with groups of a certain number of students. The number of the group depends on the scope of the assignment, under the circumstances that each student has a share in the collective work. The groups are organized by the teacher, nominating one student who would be responsible, coordinating the activity of the members: collecting working material (excerpts from various sources, observations, etc.). As soon as the groups sort the work material, they present it in class. For that purpose, they ought to use a video projector. Noted that computer technology offers great opportunities for presentation of the models, particularly is recommended the PowerPoint application that is easy to use, economical, practical and functional. Nowadays, all high school students have computer skills, added the teacher's help, they will quickly learn how to construct the so-called "moving models", in which the actors' characters effectively fill in the actantial spotlights, when this dynamic activity is simultaneously supported by short and instructive comments (written on slides) as well as the presenter's spoken comments. In that manner, one should not "experiment" with the numerous exhibitionist possibilities that would distract listeners (and viewers). The PowerPoint application development and presentation will be explained separately.

Now, the focus would be more specifically added on some activities that can be applied to teaching Macedonian language, more precisely in the subject area - literature.

Filling the Boolean matrix as a starting point. This can be done individually or in groups. Procedure: groups are formed as many ranks (and pictures) in the drama; stencils are made at home in Excel; one student reads the situations; in the end, the composition is "assembled" in order that it gives a clear idea of the dramatic summary.

Lastly, the teacher and the students evaluate the activity, taking into consideration the following elements: accuracy of the record (number of characters in the situation), sequence of the situations, and referencing skill (accuracy, clarity, diction).

At a more advanced stage, other versions of the Boolean matrices can also be made, for instance, taking into account only characters with dialogical participation (eliminating those characters that have no replica). Character rankings can also be made according to the criteria already described in the theoretical section.

\section{Topic}

Filling out the actantial models is a simple activity. The teacher forms as many groups as there are acts, and each group consist of the same number of students as situations. Hence, each student has a Boolean matrix of drama in front of him/her, which analyzes and elaborates the given situation, separating a possible subject with the other actants. Then, the group members jointly (led by the student who is responsible in that situation) determine the dramatically productive models, and the others eliminate them. They perform this activity on their own. During the lesson, the group representatives present separate models and together they determine the main actantial model.

Evaluation: It is evaluated the skill of defining a model with a clearly expressed predicate, the formulation of actors in other actantial locations (especially in the addresser and the addressee), "reading" the model, and analyzing the arguments.

\section{Subtopic}

During this activity are formed up to four groups for each model. Therefore, e.g., for the play "Chorbaji Theodos" in which we have four subjects: Theodos, Arso, Tomce and the Romani (in a weaker position), we need a maximum of sixteen groups. But since the most important are the psychological, ideological, and the active triangles, the number of groups can be reduced. As an alternative, if we work on the drama Antigone (Sophocles) where we have two dominant entities Antigone and Creon (Haemon is in a weaker position), we will form a maximum of eight groups, or optimally six. As we can conclude, throughout this project activity, the teacher can 
maximize the individualization of teaching, practically giving every student in the class the opportunity to show initiative in one class only.

With the Boolean matrix in front of them, the groups work independently: they construct and fill in the act spaces and write excerpts (replicas or dialogical fragments) as arguments that they will elaborate on later. The next phase is also an individual work that is coordinated by the group leader, which is followed by a joint development of the PowerPoint application. The final activity is presentation of the slides, followed by an explanation by the presenters, with the participation of other group members.

\section{Evaluation: as in the previous activity.}

\section{Data Analysis}

The abovementioned models could also be detected in dramas of more complex structure, such as: "Antigone" (Sophocles), "Sid" (Corney), "Hamlet" (Shakespeare), "Tartiff” (Moliere), "Uncle Vanja" (Chekhov), "Divo Meso"(Stefanovski) and others, as well as some bit plays such as "Antica "(Krle) and "Chorbaji Theodos" (Iljoski).

The procedure is the same as it was in the previously described activity, even though now it possesses a more polemical character. For instance, if it is Antigona, the teacher forms two groups that accomplish the project in two main stages: presentation and controversy. This activity is best organized in two consecutive lessons.

The controversy should have a well-formed structure and a well-planned succession of parts. The teacher appoints one chief arbitrator (who acts in a role of a judge), coordinators (one for each model) and four rapporteurs (one for each actantial triangle).

The presentation requires not only good preparation, but also high expertise from the teacher. He/she should have a good outline of the general structure of the controversy and assist the coordinators in formulating the individual phases. The aim is: opposing groups defend the actantial position of the subject (from the model they work on), semantically analyzing the addressee and the addresser, thereby arguing the action as an alternative to the closed microcosm of the dramatic fiction.

Skilfully leading this debate, the arbiter judge will point out the drama by revealing the dramatic dilemma of the main, opposing characters, who, at the cost of difficult temptations and great sacrifices, reveal to readers and viewers complex philosophical truths not only for them but also for man in general. That is the case with "Antigone", "Hamlet", but also with other, cutting-edge plays from different literary eras.

\section{Conclusion}

The teacher of Macedonian language and literature, who knows the actantial model not only formally-theoretically but also as an effective methodical tool, can develop the teaching of his/her subject (especially in the field of drama) very inventively and raise it to a high quality level. That means that the actantial analysis should be organized as a vertical reading and only in that manner it is the real challenge in the project activity in which the student is in the foreground.

Observing the drama models that are present in the secondary education curriculum, can be stated that they could be systematized into several drama groups by:

- Multiple equal subjects;

- Two equal subjects;

- One subject;

- Subject that does not cover the whole dramatic composition;

- $\quad$ Subject with typified addressees;

- Models with synecdochial actantial transformations;

- Comparative analytical methods (between two plays, as well as between plays of different style formations);

- Comparative Analysis of Actual Triangles; 
ISSN 2661-2666 (Online) International Scientific Journal Monte (ISJM) DOI: 10.33807/monte.202004636

- Comparative Approach: Actantial Model, Surio's Functions, Prop's Functions, Finite Geometric Figures;

Limits of the Actantial Analysis. 
ISSN 2661-2666 (Online) International Scientific Journal Monte (ISJM) DOI: 10.33807/monte.202004636

\section{References}

Vangelov, A (n.d). Prose Theory, Detska Radost, Skopje.

Nikolovska, V. (2018) PhD Dissertation, The Actantial Model in teaching Macedonian language and literature, Faculty of Pedagogy - Bitola.

Stojanovski, J. (2002) The Poetics of Macedonian bit - social Drama,

University Ss. Clement of Ohrid, Faculty of Pedagogy, Bitola.

Todorov, C. (1991) Poetics (French translation and prologue by Atanas Vangelov),

Skopje, Nasha Kniga.

Ibersveld, A. (1983) Čitanje pozoriša, Belgrade, Vuk Karadžić.

Nikolovski, A. (1988) Teaching Interpretation - Literature Class, Skopje. 